\title{
Competence of blended coagulants for surface water treatment
}

\author{
Vara Saritha $^{1}\left[\right.$ ] Manoj Kumar Karnena ${ }^{1}\left[\right.$ [D $\cdot$ Bhavya Kavitha Dwarapureddi ${ }^{1}$
}

Received: 11 July 2018 / Accepted: 22 November 2019 / Published online: 2 December 2019

(C) The Author(s) 2019

\begin{abstract}
Owing to the advantages of the natural coagulants under study, the present objective is to study the efficiency of blended coagulants: alum and chitin; alum and sago; and alum + chitin + sago. In this attempt, we have reduced the quantity of alum dose and added increasing quantities of the natural coagulants. The surface water samples collected from nearby sources were analyzed for the following parameters pre- and post-treatment with the coagulants. Coagulation and flocculation experiments were carried out using conventional jar test apparatus. Turbidity removal was observed to be nearly $99.29 \%$ at all pH ranges and doses. Removal of conductivity, solids and hardness was $58.83 \%, 32.03 \%$ and $33.33 \%$, respectively. From the results obtained, it can be observed that the efficiency of blended coagulants in removal of various physicochemical parameters from the waters was better when compared to individual coagulants. The floc size in blend coagulants was larger than that of single coagulants. The data obtained in this study indicated the coagulation efficiency could be enhanced by using the blend coagulant.
\end{abstract}

Keywords Dissolved organic carbon (DOC) $\cdot$ Turbidity $\cdot$ Blended coagulant $\cdot$ Dose

\section{Introduction}

It has been understood that the efficiency of coagulation is influenced by certain factors, such as $\mathrm{pH}$, temperature, alkalinity, coagulant type and mixing intensity (Camp and Root 1940; Kawamura 1976; Morris and Knocke 1984; Mhaisalkar et al. 1991; Muyibi and Evison 1995; Rossini et al. 1999). Many researchers have recommended a $\mathrm{pH}$ adjustment method to enhance the coagulation efficiency (Semmens and Field 1980; Gregor et al. 1997; Myung et al. 2001). Temperature is also a critical factor in the removal of turbidity (Myung et al. 2001; Vara 2012). Dharmappa et al. 1993 focused on rapid mix parameters as a critical parameter for optimizing the coagulation process. Specific values were suggested for the optimal detention time and intensity of rapid mix by Mhaisalkar et al. 1991. Sludge dewater ability is known as one economic factor in water treatment that affects the condition of $\mathrm{pH}$, temperature, viscosity and so on.

Vara Saritha

Vsjr08@gmail.com

1 Department of Environmental Studies, GITAM Institute of Science, GITAM (Deemed to be University), Visakhapatnam, Andhra Pradesh 530045, India
Preceding two objectives have studied some of the said governing factors and optimized them. From the second objective, it is observed that the natural coagulants, though efficient in removing various physicochemical parameters, are leaving dissolved organic content in water, which was analyzed using total organic carbon. The advantages of natural coagulants over alum can be described as being renewable, contributing to a sustainable and economical water treatment. These coagulants decrease the volume of sludge and do not alter the $\mathrm{pH}$ of the water under treatment, comparatively to conventional products based on metallic salts, and also application on a large $\mathrm{pH}$ range (6 to 8 ), without much alteration of the effluents $\mathrm{pH}$.

Coagulation for removal of DOC and turbidity has been reported to be improved when the coagulant is made with a one-to-one blend, for example, alum and ferric chloride compared to a single coagulant. Morris and Knocke reported that ferric chloride was less influenced at a low temperature compared with alum, and they suggest the combination of alum and ferric chloride as a potential method (Morris and Knocke 1984). Recent studies have tested blending alum with natural coagulants in order to reduce the sludge originating from alum and at the same time to reduce the dissolved organic matter caused due to natural coagulants 
(Halkude and Pise 2013; Saritha et al. 2019; Dwarapureddi et al. 2018).

Owing to the advantages of the natural coagulants under study, observed from the above two objectives and previous studies, the present objective is to study the efficiency of blended coagulants: alum and chitin; alum and sago; and alum + chitin + sago. In this attempt, we have reduced the quantity of alum dose and added increasing quantities of the natural coagulants.

\section{Methodology}

\section{Preparation of blended coagulants}

Natural coagulants were blended with alum to obtain four ratios, keeping alum concentration standard and increasing the concentrations of the natural coagulants:

Alum + chitin-1:1;1:2;1:3 and $1: 4$

Alum + sago- $1: 1 ; 1: 2 ; 1: 3$ and $1: 4$

Alum + chitin + sago-1:1;1:2;1:3 and 1:4

Each ratio is again tested in four concentrations, i.e., 0.2 , $0.4,0.6$ and $0.8 \mathrm{mg} / \mathrm{l}$, which are coded with reference to the $\mathrm{pH}$ range as follows:

\section{Preparation of synthetic turbid water samples}

The turbidity of raw surface water usually varies from 10 to $500 \mathrm{NTU}$ for maximum duration of the year. Hence in the present study, two different turbidities 70 and 150 NTU were selected which come under moderate turbidity values. Synthetic turbid water samples were prepared by mixing $5 \mathrm{gm}$ of bentonite clay into $500 \mathrm{ml}$ distilled water (Fig. 1). This mixed sample was allowed to soak for $24 \mathrm{~h}$ after which the suspension was stirred to achieve uniform and homogeneous

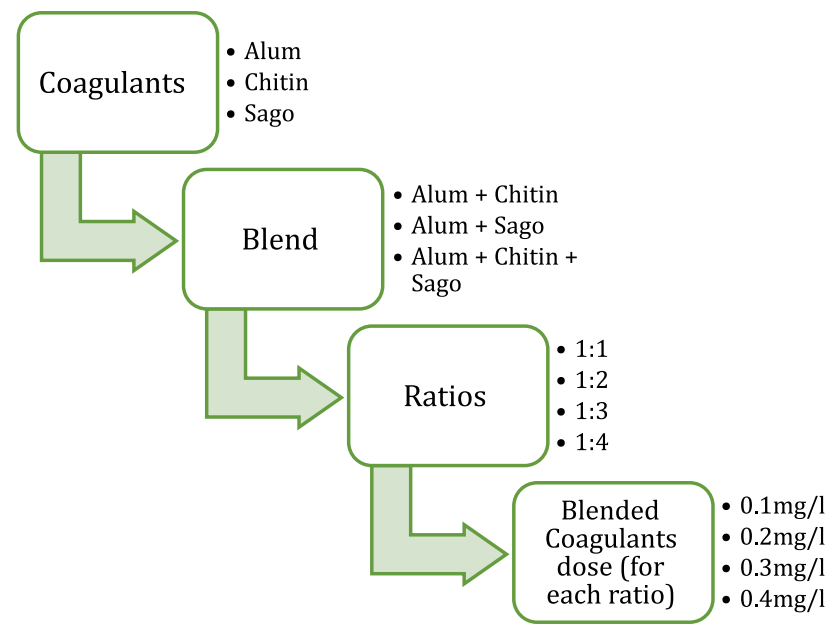

Fig. 1 Flowchart of the methodology adopted for blended coagulants sample. Turbidity of the supernatant was determined, and portions of suspension were diluted to desired turbidity values (Gidde et al. 2008).

\section{Collection of surface water samples}

In the second stage of the experiment, coagulants were evaluated for their efficiency on turbidity removal from the surface water. The water samples were collected from a lake near Pothinamallayyapalem, located at a distance of $5 \mathrm{~km}$ from the Environmental Monitoring Laboratory, GITAM University, where the experiments were carried out. This particular water body serves as a source of domestic water for the residents nearby. Care was taken while collecting the samples so that a representative sample is obtained. All samples were collected in sterile plastic containers.

The samples were transported to the laboratory, and all the experiments were conducted within duration of $24 \mathrm{~h}$. The physical parameters like temperature and color were noted at the point of sample collection. The water samples were analyzed for the following parameters pre- and post-treatment with the coagulants (Table 1). The coagulants were tested at various concentrations like $0.1,0.2,0.3$ and $0.4 \mathrm{mg} / \mathrm{l}$ at three $\mathrm{pH}$ ranges of 6,7 and 8 .

\section{Experimental procedure}

Coagulation and flocculation experiments were carried out using conventional jar test apparatus. Two-liter beakers were used with one liter water samples (synthetic and surface) along with coagulant doses of $0.1,0.2,0.3$ and $0.4 \mathrm{mg} / \mathrm{l}$. Mixing speed and time which is a governing factor for the process has been optimized in the previous studies to $100 \mathrm{rpm}$ for $1 \mathrm{~min}$ and then reduced to $20 \mathrm{rpm}$ for $30 \mathrm{~min}$. Experiments were carried out at three $\mathrm{pH}$ ranges generally existing in the surface water, i.e., 6, 7 and 8. $\mathrm{pH}$ was adjusted using $0.1 \mathrm{M} \mathrm{H}_{2} \mathrm{SO}_{4}$ and $0.1 \mathrm{M}$ $\mathrm{NaOH}$ for synthetic waters. Twenty min was given for sedimentation, after which an aliquot of $10 \mathrm{ml}$ was taken from the mid-depth of the beaker and residual turbidity was determined. Turbidity measurements were conducted

Table 1 Codes and their respective denotes

\begin{tabular}{cccccl}
\hline Code & Definition & Code & Definition & Code & Definition \\
\hline $6 \mathrm{a}$ & $\begin{array}{c}6 \mathrm{pH}-0.1 \\
\text { dose }\end{array}$ & $7 \mathrm{a}$ & $\begin{array}{c}7 \mathrm{pH}-0.1 \\
\text { dose }\end{array}$ & $8 \mathrm{a}$ & $8 \mathrm{pH}-0.1$ dose \\
$6 \mathrm{~b}$ & $\begin{array}{c}6 \mathrm{pH}-0.2 \\
\text { dose }\end{array}$ & $7 \mathrm{~b}$ & $\begin{array}{c}7 \mathrm{pH}-0.2 \\
\text { dose }\end{array}$ & $8 \mathrm{~b}$ & $8 \mathrm{pH}-0.2$ dose \\
$6 \mathrm{c}$ & $\begin{array}{c}6 \mathrm{pH}-0.3 \\
\text { dose }\end{array}$ & $7 \mathrm{c}$ & $\begin{array}{c}7 \mathrm{pH}-0.3 \\
\text { dose }\end{array}$ & $8 \mathrm{c}$ & $8 \mathrm{pH}-0.3$ dose \\
$6 \mathrm{~d}$ & $\begin{array}{c}6 \mathrm{pH}-0.4 \\
\text { dose }\end{array}$ & $7 \mathrm{~d}$ & $\begin{array}{c}7 \mathrm{pH}-0.4 \\
\text { dose }\end{array}$ & $8 \mathrm{~d}$ & $8 \mathrm{pH}-0.4$ dose \\
\hline
\end{tabular}


using nephelometric turbidimeter (ELICO, CL52D). The $\mathrm{pH}$ values of samples were measured using $\mathrm{pH}$ meter (ELICO, L1 126).

\section{Results}

\section{Alum + Chitin (1:1 ratio)}

Table 2 presents the results obtained from treatment of water with blended coagulant (alum + chitin) with ratio $1: 1$. Turbidity removal was observed to be highest with $99.29 \%$ at $6 \mathrm{pH}$ and $0.15 \mathrm{mg} / \mathrm{l}$ dose. Conductivity removal was stable with $58.83 \%$ at most of the $\mathrm{pH}$ and doses. Total solids reduction was observed to be $32.03 \%$ at $6 \mathrm{pH}$ and $0.15 \mathrm{mg} / \mathrm{l}$ dose. Removal of magnesium hardness was stable with $33.33 \%$, in similar lines with alkalinity $42.86 \%$. Chloride concentration has enhanced with $-52.64 \%$.

\section{Alum + Chitin (1:2 ratio)}

Table 3 presents the results obtained from treatment of water with blended coagulant (alum + chitin) with ratio 1:2. Turbidity removal was observed to be highest with $100 \%$ at most of the $\mathrm{pH}$ ranges and doses of coagulants. Conductivity removal was observed to be highest with $54.11 \%$ at $8 \mathrm{pH}$. Total dissolved solids concentration has increased. Removal of magnesium hardness was stable with $33.33 \%$, in similar lines with alkalinity $42.86 \%$. Chloride concentration has enhanced with $-10.53 \%$.

\section{Alum + Chitin (1:3 ratio)}

Table 4 presents the results obtained from treatment of water with blended coagulant (alum + chitin) with ratio 1:3. Turbidity removal was observed to be highest with $98.94 \%$ at 6 $\mathrm{pH}$ and 0.15 and $0.20 \mathrm{mg} / \mathrm{l}$ doses of coagulants. Conductivity removal was observed to be highest with $53.17 \%$ at $8 \mathrm{pH}$
Table 2 Percentage reduction in various physicochemical parameters of surface water after treatment with blended coagulant (alum + chitin-1:1 ratio)

\begin{tabular}{llllllll}
\hline Code & Conductivity & Turbidity & \multicolumn{1}{l}{ TDS } & \multicolumn{1}{l}{ TH } & MH & Alkalinity & Chlorides \\
\hline 6a & 58.83 & 88.65 & 11.63 & -20.83 & 33.33 & 42.86 & -52.64 \\
6b & 58.83 & 90.07 & 13.05 & -20.83 & 33.33 & 42.86 & -52.64 \\
6c & 58.83 & 99.29 & 32.03 & -20.83 & 33.33 & 42.86 & -52.64 \\
6d & 58.83 & 98.94 & 25.34 & -20.83 & 33.33 & 42.86 & -52.64 \\
$7 \mathrm{a}$ & 56.00 & 95.04 & 8.26 & -20.83 & 33.33 & 42.86 & -52.64 \\
$7 \mathrm{~b}$ & 56.94 & 91.84 & 7.87 & -20.83 & 33.33 & 42.86 & -52.64 \\
$7 \mathrm{c}$ & 57.89 & 91.49 & 7.68 & -20.83 & 33.33 & 42.86 & -52.64 \\
$7 \mathrm{~d}$ & 56.00 & 98.23 & 8.26 & -20.83 & 33.33 & 42.86 & -52.64 \\
8a & 58.83 & 90.07 & -1.41 & -20.83 & 33.33 & 42.86 & -52.64 \\
8b & 58.83 & 88.65 & 0.23 & -20.83 & 33.33 & 42.86 & -52.64 \\
8c & 58.83 & 96.45 & 2.04 & -20.83 & 33.33 & 42.86 & -52.64 \\
8d & 58.83 & 88.65 & 3.13 & -20.83 & 33.33 & 42.86 & -52.64 \\
\hline
\end{tabular}

TDS total dissolved solids, $T H$ total hardness, $M H$ magnesium hardness

\begin{tabular}{llrlllll}
\hline Code & Conductivity & Turbidity & TDS & Hardness & MH & Alkalinity & Chlorides \\
\hline 6a & 34.30 & 91.13 & -12.45 & -20.83 & 33.33 & 42.86 & -10.53 \\
6b & 31.47 & 100.00 & -10.24 & -20.83 & 33.33 & 42.86 & -10.53 \\
6c & 35.25 & 99.29 & -11.30 & -20.83 & 33.33 & 42.86 & -10.53 \\
6d & 35.25 & 100.00 & -12.07 & -20.83 & 33.33 & 42.86 & -10.53 \\
7a & 33.36 & 100.00 & -10.38 & -20.83 & 33.33 & 42.86 & -10.53 \\
7b & 42.79 & 100.00 & -23.19 & -20.83 & 33.33 & 42.86 & -10.53 \\
7c & 41.85 & 98.58 & -21.75 & -20.83 & 33.33 & 42.86 & -10.53 \\
7d & 39.02 & 90.07 & -18.86 & -20.83 & 33.33 & 42.86 & -10.53 \\
8a & 55.06 & 100.00 & -33.72 & -20.83 & 33.33 & 42.86 & -10.53 \\
8b & 53.17 & 97.16 & -33.87 & -20.83 & 33.33 & 42.86 & -10.53 \\
8c & 53.17 & 90.07 & -34.84 & -20.83 & 33.33 & 42.86 & -10.53 \\
8d & 54.11 & 94.33 & -33.78 & -20.83 & 33.33 & 42.86 & -10.53 \\
\hline
\end{tabular}

TDS total dissolved solids, $T H$ total hardness, $M H$ magnesium hardness

TDS total dissolved solids, TH total hardness, MH magnesium hardness
Table 3 Percentage reduction in various physicochemical parameters of surface water after treatment with blended coagulant (alum + chitin-1:2 ratio) 
Table 4 Percentage reduction in various physicochemical parameters of surface water after treatment with blended coagulant (alum + chitin-1:3 ratio)

\begin{tabular}{llllllll}
\hline Code & Conductivity & Turbidity & TDS & TH & MH & Alkalinity & Chlorides \\
\hline 6a & 51.28 & 95.04 & 4.49 & -20.83 & 0.00 & 42.86 & -10.53 \\
6b & 45.62 & 93.62 & 4.22 & -20.83 & 0.00 & 42.86 & -10.53 \\
6c & 45.62 & 98.94 & 3.45 & -20.83 & 0.00 & 42.86 & -10.53 \\
6d & 45.62 & 98.58 & 3.79 & -20.83 & 0.00 & 42.86 & -10.53 \\
$7 \mathrm{a}$ & 48.45 & 94.68 & 4.66 & -20.83 & 0.00 & 42.86 & -10.53 \\
$7 \mathrm{~b}$ & 51.28 & 94.68 & 3.83 & -20.83 & 0.00 & 42.86 & -10.53 \\
$7 \mathrm{c}$ & 48.45 & 96.45 & 4.26 & -20.83 & 0.00 & 42.86 & -10.53 \\
$7 \mathrm{~d}$ & 50.34 & 94.68 & 4.66 & -20.83 & 0.00 & 42.86 & -10.53 \\
$8 \mathrm{a}$ & 53.17 & 94.68 & 0.00 & -20.83 & 0.00 & 42.86 & -10.53 \\
$8 \mathrm{~b}$ & 52.23 & 95.04 & 1.84 & -20.83 & 0.00 & 42.86 & -10.53 \\
$8 \mathrm{c}$ & 49.40 & 94.68 & 2.26 & -20.83 & 0.00 & 42.86 & -10.53 \\
$8 \mathrm{~d}$ & 47.51 & 95.04 & 2.24 & -20.83 & 0.00 & 42.86 & -10.53 \\
\hline
\end{tabular}

TDS total dissolved solids, $T H$ total hardness, $M H$ magnesium hardness and $0.05 \mathrm{mg} / \mathrm{l}$ dose. Total dissolved solids reduction was very less ranging from 0 to $4.49 \%$. Total hardness concentration has increased and so is the concentration of chlorides. Alkalinity reduction was $42.86 \%$.

\section{Alum + Chitin (1:4 ratio)}

Table 5 presents the results obtained from treatment of water with blended coagulant (alum + chitin) with ratio 1:4. Turbidity removal was observed to be highest with $99.24 \%$ at $8 \mathrm{pH}$ and $0.1 \mathrm{mg} / \mathrm{l}$ dose of coagulant. Conductivity removal was observed to be within the range of $47.51-51.28 \%$. Total dissolved solids reduction was very less ranging from 0 to $4.49 \%$. Total hardness concentration has increased and so is the concentration of chlorides and alkalinity.

Figure 2 demonstrates the sludge obtained from the treatment, and it is observed that the sludge concentration was directly proportional to the dose of the coagulant and increase in $\mathrm{pH}$.

\section{Alum + Sago (1:1 ratio)}

Table 6 presents the results obtained from treatment of water with blended coagulant (alum + sago) with ratio 1:1. Turbidity removal was observed to be in the range of 98.58 to $99.24 \%$. Conductivity removal was observed to be highest of $50.34 \%$ at $\mathrm{pH} 8$ and $0.15 \mathrm{mg} / \mathrm{l}$ dose. Total dissolved solids reduction was highest with $43.40 \%$ at $6 \mathrm{pH}$ and $0.20 \mathrm{mg} / \mathrm{l}$ dose. Total hardness concentration has increased and so is the concentration of calcium hardness and chlorides. Alkalinity reduction was stable with $42.86 \%$.

\section{Alum + Sago (1:2 ratio)}

Table 7 presents the results obtained from treatment of water with blended coagulant (alum + sago) with ratio 1:2. Turbidity removal was observed in the range of 94.68 to $97.87 \%$. Conductivity removal was observed in the range of 45.62 to $49.40 \%$. Total dissolved solids reduction was very less with
Table 5 Percentage reduction in various physicochemical parameters of surface water after treatment with blended coagulant (alum + chitin-1:4 ratio)

\begin{tabular}{llllllll}
\hline Code & Conductivity & Turbidity & TDS & TH & MH & Alkalinity & Chlorides \\
\hline 6a & 51.28 & 95.39 & 4.49 & -20.83 & 0.00 & -28.57 & -10.53 \\
6b & 51.28 & 93.62 & 4.22 & -20.83 & 0.00 & -28.57 & -10.53 \\
6c & 50.34 & 95.39 & 3.45 & -20.83 & 0.00 & -28.57 & -10.53 \\
6d & 51.28 & 95.39 & 3.79 & -20.83 & 0.00 & -28.57 & -10.53 \\
$7 \mathrm{a}$ & 51.28 & 95.39 & 4.66 & -20.83 & 0.00 & -28.57 & -10.53 \\
$7 \mathrm{~b}$ & 50.34 & 93.62 & 3.83 & -20.83 & 0.00 & -28.57 & -10.53 \\
$7 \mathrm{c}$ & 50.34 & 93.62 & 4.26 & -20.83 & 0.00 & -28.57 & -10.53 \\
$7 \mathrm{~d}$ & 51.28 & 95.39 & 4.66 & -20.83 & 0.00 & -28.57 & -10.53 \\
$8 \mathrm{a}$ & 49.40 & 93.97 & 0.00 & -20.83 & 0.00 & -28.57 & -10.53 \\
$8 \mathrm{~b}$ & 52.23 & 99.29 & 1.84 & -20.83 & 0.00 & -28.57 & -10.53 \\
8c & 51.28 & 97.16 & 2.26 & -20.83 & 0.00 & -28.57 & -10.53 \\
8d & 47.51 & 98.94 & 2.24 & -20.83 & 0.00 & -28.57 & -10.53 \\
\hline
\end{tabular}

TDS total dissolved solids, $T H$ total hardness, $M H$ magnesium hardness 
Fig. 2 Sludge weight $(\mathrm{mg} / \mathrm{l})$ obtained from water treated with blended coagulant (alum + chitin)
Sludge weight (mg/l) obtained from water treated with blended coagulant (alum + chitin)

1.6

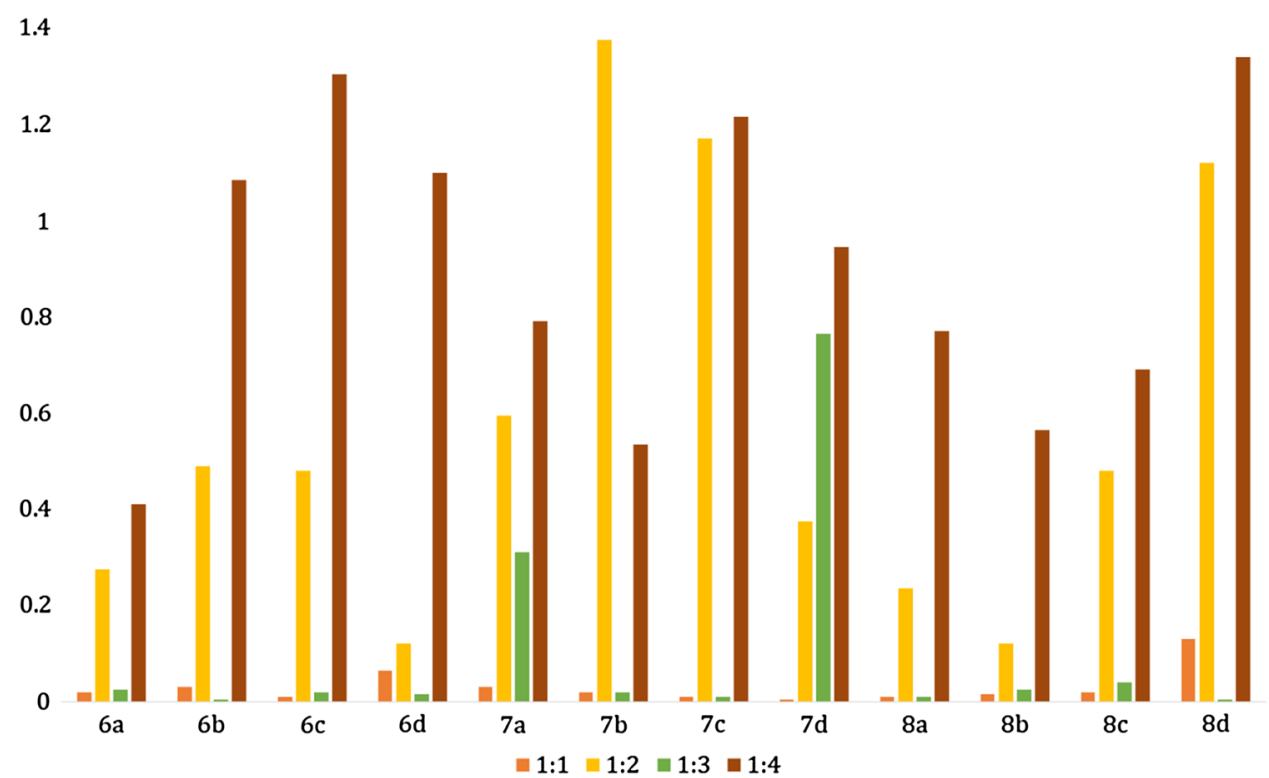

Table 6 Percentage reduction in various physicochemical parameters of surface water after treatment with blended coagulant (alum + sago- $1: 1$ ratio)

\begin{tabular}{llllrlllll}
\hline Code & Conductivity & Turbidity & Total solids & \multicolumn{1}{l}{ TDS } & \multicolumn{1}{l}{ TH } & CH & MH & Alkalinity & Chlorides \\
\hline 6a & 28.64 & 98.58 & 60.00 & 31.60 & -20.83 & -55.56 & 0.00 & 42.86 & -52.64 \\
6b & 14.49 & 98.58 & 50.00 & 42.27 & -20.83 & -55.56 & 0.00 & 42.86 & -52.64 \\
6c & 26.75 & 98.58 & 50.00 & 31.49 & -20.83 & -55.56 & 0.00 & 42.86 & -52.64 \\
6d & 13.55 & 98.58 & 50.00 & 43.40 & -20.83 & -55.56 & 0.00 & 42.86 & -52.64 \\
7a & 45.62 & 98.58 & 30.00 & 6.88 & -20.83 & -55.56 & 0.00 & 42.86 & -52.64 \\
7b & 44.68 & 98.58 & 10.00 & 9.60 & -20.83 & -55.56 & 0.00 & 42.86 & -52.64 \\
7c & 41.85 & 98.58 & 20.00 & 11.45 & -20.83 & -55.56 & 0.00 & 42.86 & -52.64 \\
7d & 49.40 & 98.58 & -10.00 & 14.76 & -20.83 & -55.56 & 0.00 & 42.86 & -52.64 \\
8a & 49.40 & 99.29 & 50.00 & -1.17 & -20.83 & -55.56 & 0.00 & 42.86 & -52.64 \\
8b & 50.34 & 99.29 & 40.00 & 0.00 & -20.83 & -55.56 & 0.00 & 42.86 & -52.64 \\
8c & 39.96 & 99.29 & 40.00 & 1.14 & -20.83 & -55.56 & 0.00 & 42.86 & -52.64 \\
8d & 47.51 & 99.29 & 70.00 & 2.26 & -20.83 & -55.56 & 0.00 & 42.86 & -52.64 \\
\hline
\end{tabular}

TDS total dissolved solids, $T H$ total hardness, $M H$ magnesium hardness highest reduction of $4.34 \%$ at $8 \mathrm{pH}$ and $0.15 \mathrm{mg} / \mathrm{l}$ dose. Total hardness concentration has increased and so is the concentration of calcium hardness and chlorides. Alkalinity reduction was stable with $42.86 \%$.

\section{Alum + Sago (1:3 ratio)}

Table 8 presents the results obtained from treatment of water with blended coagulant (alum + sago) with ratio 1:3. Turbidity removal was observed in the range of 89.01 to $100 \%$. Conductivity removal was observed to be less at $\mathrm{pH} 6$ in the range of 13.55 to $17.32 \%$ which increased with increased dose of the coagulant. Highest conductivity reduction was observed with $0.15 \mathrm{mg} / \mathrm{l}$ at $\mathrm{pH}$ 8. Total solids reduction was observed to be $90 \%$ at pH 7 and $0.20 \mathrm{mg} / \mathrm{l}$ dose. Total dissolved solids reduction was highest with $41.46 \%$ at $6 \mathrm{pH}$ $0.15 \mathrm{mg} / \mathrm{l}$. Total hardness concentration has increased and so is the concentration of calcium hardness and chlorides. Alkalinity reduction was stable with $42.86 \%$.

\section{Alum + Sago (1:4 ratio)}

Table 9 presents the results obtained from treatment of water with blended coagulant (alum + sago) with ratio 1:4. Turbidity removal was observed in the range of 90.07 to $96.45 \%$. Conductivity removal was stable with $46.57 \%$.

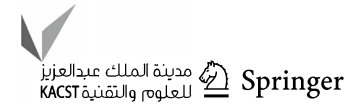


Table 7 Percentage reduction in various physicochemical parameters of surface water after treatment with blended coagulant (alum + sago $-1: 2$ ratio)
Table 8 Percentage reduction in various physicochemical parameters of surface water after treatment with blended coagulant (alum + sago- $-1: 3$ ratio)
Table 9 Percentage reduction in various physicochemical parameters of surface water after treatment with blended coagulant (alum + sago- $1: 4$ ratio)

\begin{tabular}{llllllllll}
\hline Code & Conductivity & Turbidity & Total solids & TDS & TH & CH & MH & Alkalinity & Chlorides \\
\hline 6a & 48.45 & 95.74 & 80.00 & 3.63 & -20.83 & -55.56 & 0.00 & 42.86 & -26.33 \\
6b & 47.51 & 96.45 & 40.00 & 3.33 & -20.83 & -55.56 & 0.00 & 42.86 & -26.33 \\
6c & 48.45 & 96.45 & 40.00 & 4.27 & -20.83 & -55.56 & 0.00 & 42.86 & -26.33 \\
6d & 47.51 & 95.74 & 40.00 & 4.18 & -20.83 & -55.56 & 0.00 & 42.86 & -26.33 \\
7a & 48.45 & 94.68 & 100.00 & 1.94 & -20.83 & -55.56 & 0.00 & 42.86 & -26.33 \\
7b & 49.40 & 94.33 & 70.00 & 2.71 & -20.83 & -55.56 & 0.00 & 42.86 & -26.33 \\
7c & 48.45 & 95.04 & 50.00 & 3.68 & -20.83 & -55.56 & 0.00 & 42.86 & -26.33 \\
7d & 49.40 & 94.68 & 40.00 & 2.36 & -20.83 & -55.56 & 0.00 & 42.86 & -26.33 \\
8a & 45.62 & 97.16 & 70.00 & 3.27 & -20.83 & -55.56 & 0.00 & 42.86 & -26.33 \\
8b & 47.51 & 97.52 & 50.00 & 2.77 & -20.83 & -55.56 & 0.00 & 42.86 & -26.33 \\
8c & 47.51 & 97.87 & 40.00 & 4.34 & -20.83 & -55.56 & 0.00 & 42.86 & -26.33 \\
8d & 48.45 & 97.16 & 60.00 & 4.06 & -20.83 & -55.56 & 0.00 & 42.86 & -26.33 \\
\hline
\end{tabular}

TDS total dissolved solids, $T H$ total hardness, $M H$ magnesium hardness

\begin{tabular}{llcccccccc}
\hline Code & Conductivity & Turbidity & Total solids & TDS & \multicolumn{1}{l}{ TH } & CH & MH & Alkalinity & Chlorides \\
\hline 6a & 13.55 & 89.01 & 40.00 & 39.65 & -20.83 & -55.56 & 0.00 & 42.86 & -26.33 \\
6b & 13.55 & 99.65 & 40.00 & 32.40 & -20.83 & -55.56 & 0.00 & 42.86 & -26.33 \\
6c & 14.49 & 97.52 & 40.00 & 41.46 & -20.83 & -55.56 & 0.00 & 42.86 & -26.33 \\
6d & 17.32 & 97.87 & 20.00 & 31.37 & -20.83 & -55.56 & 0.00 & 42.86 & -26.33 \\
7a & 46.57 & 95.39 & 60.00 & 11.61 & -20.83 & -55.56 & 0.00 & 42.86 & -26.33 \\
7b & 43.74 & 98.94 & -10.00 & 11.06 & -20.83 & -55.56 & 0.00 & 42.86 & -26.33 \\
7c & 43.74 & 98.94 & 30.00 & 9.00 & -20.83 & -55.56 & 0.00 & 42.86 & -26.33 \\
7d & 42.79 & 100.00 & 90.00 & 11.42 & -20.83 & -55.56 & 0.00 & 42.86 & -26.33 \\
8a & 47.51 & 96.10 & 60.00 & 1.40 & -20.83 & -55.56 & 0.00 & 42.86 & -26.33 \\
8b & 47.51 & 98.23 & 50.00 & 0.92 & -20.83 & -55.56 & 0.00 & 42.86 & -26.33 \\
8c & 50.34 & 99.65 & 60.00 & 2.51 & -20.83 & -55.56 & 0.00 & 42.86 & -26.33 \\
8d & 48.45 & 98.94 & 40.00 & 2.71 & -20.83 & -55.56 & 0.00 & 42.86 & -26.33 \\
\hline
\end{tabular}

TDS total dissolved solids, $T H$ total hardness, $M H$ magnesium hardness

\begin{tabular}{llllllllll}
\hline Code & Conductivity & Turbidity & Total solids & TDS & TH & CH & MH & Alkalinity & Chlorides \\
\hline 6a & 46.57 & 92.55 & 70.00 & 31.60 & -20.83 & -55.56 & 0.00 & 42.86 & -26.33 \\
6b & 46.57 & 94.68 & 70.00 & 42.27 & -20.83 & -55.56 & 0.00 & 42.86 & -26.33 \\
6c & 46.57 & 92.91 & 70.00 & 31.49 & -20.83 & -55.56 & 0.00 & 42.86 & -26.33 \\
6d & 46.57 & 90.07 & 80.00 & 43.40 & -20.83 & -55.56 & 0.00 & 42.86 & -26.33 \\
7a & 46.57 & 94.33 & 80.00 & 6.88 & -20.83 & -55.56 & 0.00 & 42.86 & -26.33 \\
7b & 46.57 & 94.33 & 80.00 & 9.60 & -20.83 & -55.56 & 0.00 & 42.86 & -26.33 \\
7c & 46.57 & 96.45 & 40.00 & 11.45 & -20.83 & -55.56 & 0.00 & 42.86 & -26.33 \\
$7 \mathrm{~d}$ & 46.57 & 91.84 & 40.00 & 14.76 & -20.83 & -55.56 & 0.00 & 42.86 & -26.33 \\
8a & 46.57 & 91.13 & 70.00 & -1.17 & -20.83 & -55.56 & 0.00 & 42.86 & -26.33 \\
8b & 46.57 & 93.62 & 50.00 & 0.00 & -20.83 & -55.56 & 0.00 & 42.86 & -26.33 \\
8c & 46.57 & 93.62 & 60.00 & 1.14 & -20.83 & -55.56 & 0.00 & 42.86 & -26.33 \\
8d & 46.57 & 94.33 & 60.00 & 2.26 & -20.83 & -55.56 & 0.00 & 42.86 & -26.33 \\
\hline
\end{tabular}

TDS total dissolved solids, $T H$ total hardness, $M H$ magnesium hardness 
Total solids reduction was observed to be minimum of $40 \%$ and maximum of $80 \%$. Total dissolved solids reduction was highest with $42.27 \%$ at $6 \mathrm{pH}$ and $0.1 \mathrm{mg} / \mathrm{l}$ dose. Total hardness concentration has increased and so is the concentration of calcium hardness and chlorides. Alkalinity reduction was stable with $42.86 \%$.

Figure 3 demonstrates the sludge obtained from the treatment, and it is observed that the sludge concentration was inversely proportional to the dose of the coagulant and increase in $\mathrm{pH}$.

\section{Alum + Chitin + Sago (1:1 ratio)}

Table 10 presents the results obtained from treatment of water with blended coagulant (alum + chitin + sago) with ratio $1: 1$. Turbidity removal was observed in the range of 91.49 to $99.29 \%$. Conductivity removal was stable with $48.45 \%$. Total solids reduction was observed to be minimum of $10 \%$ and maximum of $80 \%$. Total dissolved solids reduction was highest with $23.09 \%$ at $8 \mathrm{pH}$ and $0.2 \mathrm{mg} / \mathrm{l}$ dose. Total hardness concentration has increased and so is the concentration of calcium hardness and chlorides. Alkalinity reduction was stable with $42.86 \%$.
Fig. 3 Sludge weight $(\mathrm{mg} / \mathrm{l})$ obtained from water treated with blended coagulant (alum + sago)

\section{Sludge weight $(\mathrm{mg} / \mathrm{l})$ obtained from water treated with blended coagulant (alum +} sago)

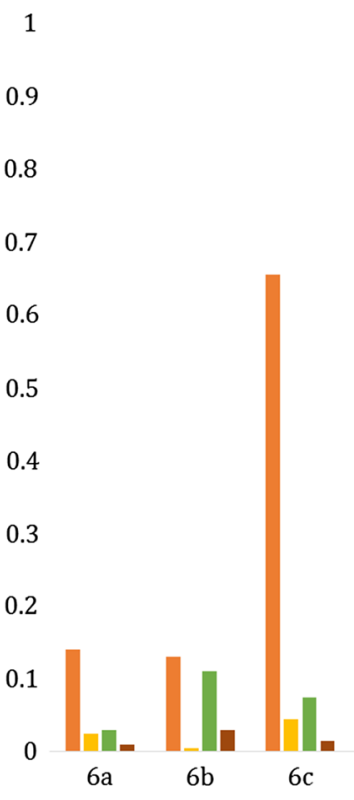

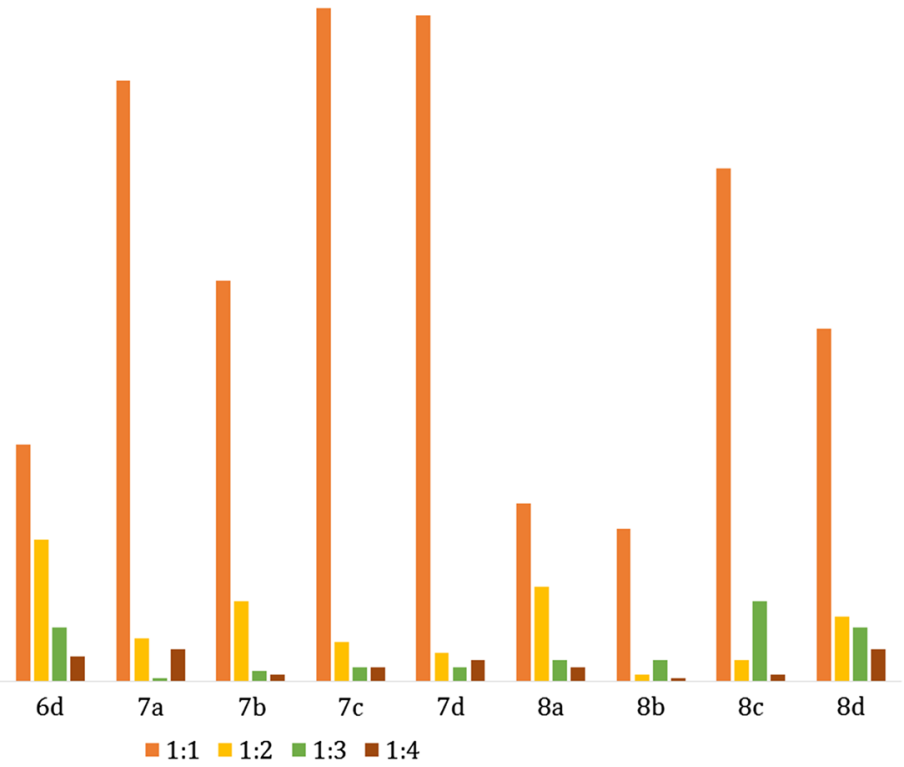

Table 10 Percentage reduction in various physicochemical parameters of surface water after treatment with blended coagulant (alum + chitin + sago-1:1 ratio)

\begin{tabular}{llllllllll}
\hline Code & Conductivity & Turbidity & Total solids & TDS & TH & CH & MH & Alkalinity & Chlorides \\
\hline 6a & 48.45 & 95.74 & 20.00 & -11.89 & -20.83 & -55.56 & 0.00 & 42.86 & -26.33 \\
6b & 48.45 & 95.74 & 30.00 & 0.23 & -20.83 & -55.56 & 0.00 & 42.86 & -26.33 \\
6c & 48.45 & 96.45 & 10.00 & 0.69 & -20.83 & -55.56 & 0.00 & 42.86 & -26.33 \\
6d & 47.51 & 95.74 & 70.00 & 20.55 & -20.83 & -55.56 & 0.00 & 42.86 & -26.33 \\
$7 \mathrm{a}$ & 48.45 & 91.84 & 70.00 & 20.26 & -20.83 & -55.56 & 0.00 & 42.86 & -26.33 \\
$7 \mathrm{~b}$ & 47.51 & 91.49 & 60.00 & 15.43 & -20.83 & -55.56 & 0.00 & 42.86 & -26.33 \\
$7 \mathrm{c}$ & 48.45 & 94.68 & -10.00 & 21.70 & -20.83 & -55.56 & 0.00 & 42.86 & -26.33 \\
$7 \mathrm{~d}$ & 47.51 & 98.94 & 30.00 & 22.12 & -20.83 & -55.56 & 0.00 & 42.86 & -26.33 \\
8a & 44.68 & 94.33 & 70.00 & 1.59 & -20.83 & -55.56 & 0.00 & 42.86 & -26.33 \\
$8 \mathrm{~b}$ & 43.74 & 95.74 & 60.00 & 23.36 & -20.83 & -55.56 & 0.00 & 42.86 & -26.33 \\
8c & 44.68 & 99.29 & 40.00 & 22.68 & -20.83 & -55.56 & 0.00 & 42.86 & -26.33 \\
8d & 43.74 & 98.58 & 80.00 & 23.09 & -20.83 & -55.56 & 0.00 & 42.86 & -26.33 \\
\hline
\end{tabular}

$T D S$ total dissolved solids, $T H$ total hardness, $M H$ magnesium hardness 
Table 11 Percentage reduction in various physicochemical parameters of surface water after treatment with blended coagulant (alum + chitin + sago- $1: 2$ ratio $)$

\begin{tabular}{llllrlllll}
\hline Code & Conductivity & Turbidity & Total solids & \multicolumn{1}{l}{ TDS } & TH & CH & MH & Alkalinity & Chlorides \\
\hline 6a & 48.45 & 95.04 & 20.00 & -11.89 & -20.83 & -55.56 & 0.00 & 42.86 & -26.33 \\
6b & 48.45 & 95.74 & 30.00 & 0.23 & -20.83 & -55.56 & 0.00 & 42.86 & -26.33 \\
6c & 47.51 & 95.74 & 10.00 & 0.69 & -20.83 & -55.56 & 0.00 & 42.86 & -26.33 \\
6d & 47.51 & 96.45 & 70.00 & 20.55 & -20.83 & -55.56 & 0.00 & 42.86 & -26.33 \\
7a & 48.45 & 84.75 & 70.00 & 20.26 & -20.83 & -55.56 & 0.00 & 42.86 & -26.33 \\
7b & 47.51 & 91.13 & 50.00 & 15.43 & -20.83 & -55.56 & 0.00 & 42.86 & -26.33 \\
$7 \mathrm{c}$ & 48.45 & 84.04 & 60.00 & 21.70 & -20.83 & -55.56 & 0.00 & 42.86 & -26.33 \\
$7 \mathrm{~d}$ & 47.51 & 93.62 & 60.00 & 22.12 & -20.83 & -55.56 & 0.00 & 42.86 & -26.33 \\
8a & 39.96 & 95.04 & 50.00 & 1.59 & -20.83 & -55.56 & 0.00 & 42.86 & -26.33 \\
8b & 40.91 & 96.10 & 60.00 & 23.36 & -20.83 & -55.56 & 0.00 & 42.86 & -26.33 \\
8c & 44.68 & 95.04 & 80.00 & 22.68 & -20.83 & -55.56 & 0.00 & 42.86 & -26.33 \\
8d & 43.74 & 91.13 & 70.00 & 23.09 & -20.83 & -55.56 & 0.00 & 42.86 & -26.33 \\
\hline
\end{tabular}

TDS total dissolved solids, $T H$ total hardness, $M H$ magnesium hardness

\section{Alum + Chitin + Sago (1:2 ratio)}

Table 11 presents the results obtained from treatment of water with blended coagulant (alum + chitin + sago) with ratio $1: 2$. Turbidity removal was observed in the range of 84.04 to $96.45 \%$. Conductivity removal was in the range of 39.96 to $48.45 \%$. Total solids reduction was observed to be minimum of $10 \%$ and maximum of $80 \%$. Total dissolved solids reduction was highest with $23.86 \%$ at $8 \mathrm{pH}$ $0.1 \mathrm{mg} / \mathrm{l}$. Total hardness concentration has increased and so is the concentration of calcium hardness and chlorides. Alkalinity reduction was stable with $42.86 \%$.

\section{Alum + Chitin + Sago (1:3 ratio)}

Table 12 presents the results obtained from treatment of water with blended coagulant (alum + chitin + sago) with ratio $1: 3$. Turbidity removal was observed in the range of 91.49 to $98.58 \%$. Conductivity removal was mostly stable with $48.45 \%$. Total solids reduction was also mostly stable ranging from 30 to $60 \%$ reduction. Total dissolved solids reduction was highest with $23.36 \%$ at $8 \mathrm{pH}$ and $0.1 \mathrm{mg} / \mathrm{l}$ dose. Total hardness concentration has increased and so is the concentration of calcium hardness and chlorides. Alkalinity reduction was stable with $42.86 \%$.

\section{Alum + Chitin + Sago (1:4 ratio)}

Table 13 presents the results obtained from treatment of water with blended coagulant (alum + chitin + sago) with ratio $1: 4$. Turbidity removal was observed in the range of 89.01 to $96.45 \%$. Conductivity removal was stable with range of 43.74 to $48.45 \%$. Total solids reduction was observed to be minimum of $10 \%$ and maximum of $80 \%$. Total dissolved solids reduction was highest with $23.09 \%$ at $8 \mathrm{pH} 0.2 \mathrm{mg} / \mathrm{l}$. Total hardness concentration has increased and so is the concentration of calcium hardness and chlorides. Alkalinity reduction was stable with $42.86 \%$.
Table 12 Percentage reduction in various physicochemical parameters of surface water after treatment with blended coagulant (alum + chitin + sago- $1: 3$ ratio $)$

\begin{tabular}{llllrlllll}
\hline Code & Conductivity & Turbidity & Total solids & \multicolumn{1}{l}{ TDS } & TH & CH & MH & Alkalinity & Chlorides \\
\hline 6a & 48.45 & 95.74 & 50.00 & -11.89 & -20.83 & 47.78 & 0.00 & 42.86 & -26.33 \\
6b & 48.45 & 95.74 & 60.00 & 0.23 & -20.83 & 47.78 & 0.00 & 42.86 & -26.33 \\
6c & 47.51 & 96.45 & 30.00 & 0.69 & -20.83 & 47.78 & 0.00 & 42.86 & -26.33 \\
6d & 47.51 & 95.74 & 40.00 & 20.55 & -20.83 & 47.78 & 0.00 & 42.86 & -26.33 \\
$7 \mathrm{a}$ & 48.45 & 91.84 & 50.00 & 20.26 & -20.83 & 47.78 & 0.00 & 42.86 & -26.33 \\
7b & 47.51 & 91.49 & 40.00 & 15.43 & -20.83 & 47.78 & 0.00 & 42.86 & -26.33 \\
$7 \mathrm{c}$ & 48.45 & 94.68 & 50.00 & 21.70 & -20.83 & 47.78 & 0.00 & 42.86 & -26.33 \\
$7 \mathrm{~d}$ & 47.51 & 98.94 & 30.00 & 22.12 & -20.83 & 47.78 & 0.00 & 42.86 & -26.33 \\
8a & 44.68 & 94.33 & 50.00 & 1.59 & -20.83 & 47.78 & 0.00 & 42.86 & -26.33 \\
8b & 43.74 & 95.74 & 50.00 & 23.36 & -20.83 & 47.78 & 0.00 & 42.86 & -26.33 \\
8c & 44.68 & 99.29 & 50.00 & 22.68 & -20.83 & 47.78 & 0.00 & 42.86 & -26.33 \\
8d & 43.74 & 98.58 & 50.00 & 23.09 & -20.83 & 47.78 & 0.00 & 42.86 & -26.33 \\
\hline
\end{tabular}

$T D S$ total dissolved solids, $T H$ total hardness, $M H$ magnesium hardness 
Table 13 Percentage reduction in various physicochemical parameters of surface water after treatment with blended coagulant (alum + chitin + sago-1:4 ratio)

\begin{tabular}{llllllllll}
\hline Code & Conductivity & Turbidity & Total solids & \multicolumn{1}{l}{ TDS } & TH & CH & MH & Alkalinity & Chlorides \\
\hline 6a & 48.45 & 95.74 & 20.00 & -11.89 & -20.83 & -55.56 & 0.00 & 42.86 & -26.33 \\
6b & 48.45 & 95.74 & 30.00 & 0.23 & -20.83 & -55.56 & 0.00 & 42.86 & -26.33 \\
6c & 47.51 & 96.45 & 10.00 & 0.69 & -20.83 & -55.56 & 0.00 & 42.86 & -26.33 \\
6d & 47.51 & 95.74 & 70.00 & 20.55 & -20.83 & -55.56 & 0.00 & 42.86 & -26.33 \\
7a & 48.45 & 91.84 & 70.00 & 20.26 & -20.83 & -55.56 & 0.00 & 42.86 & -26.33 \\
7b & 47.51 & 91.49 & 60.00 & 15.43 & -20.83 & -55.56 & 0.00 & 42.86 & -26.33 \\
7c & 48.45 & 94.68 & 40.00 & 21.70 & -20.83 & -55.56 & 0.00 & 42.86 & -26.33 \\
$7 \mathrm{~d}$ & 47.51 & 98.94 & 30.00 & 22.12 & -20.83 & -55.56 & 0.00 & 42.86 & -26.33 \\
8a & 44.68 & 92.20 & 70.00 & 1.59 & -20.83 & -55.56 & 0.00 & 42.86 & -26.33 \\
8b & 43.74 & 88.30 & 60.00 & 23.36 & -20.83 & -55.56 & 0.00 & 42.86 & -26.33 \\
8c & 44.68 & 89.01 & 40.00 & 22.68 & -20.83 & -55.56 & 0.00 & 42.86 & -26.33 \\
8d & 43.74 & 92.20 & 80.00 & 23.09 & -20.83 & -55.56 & 0.00 & 42.86 & -26.33 \\
\hline
\end{tabular}

TDS total dissolved solids, $T H$ total hardness, $M H$ magnesium hardness
Fig. 4 Sludge weight $(\mathrm{mg} / \mathrm{l})$ obtained from water treated with blended coagulant $($ alum + chitin + sago $)$
Sludge weight ( $\mathrm{mg} / \mathrm{l}$ ) obtained from water treated with blended coagulant (alum + chitin+sago)

0.14

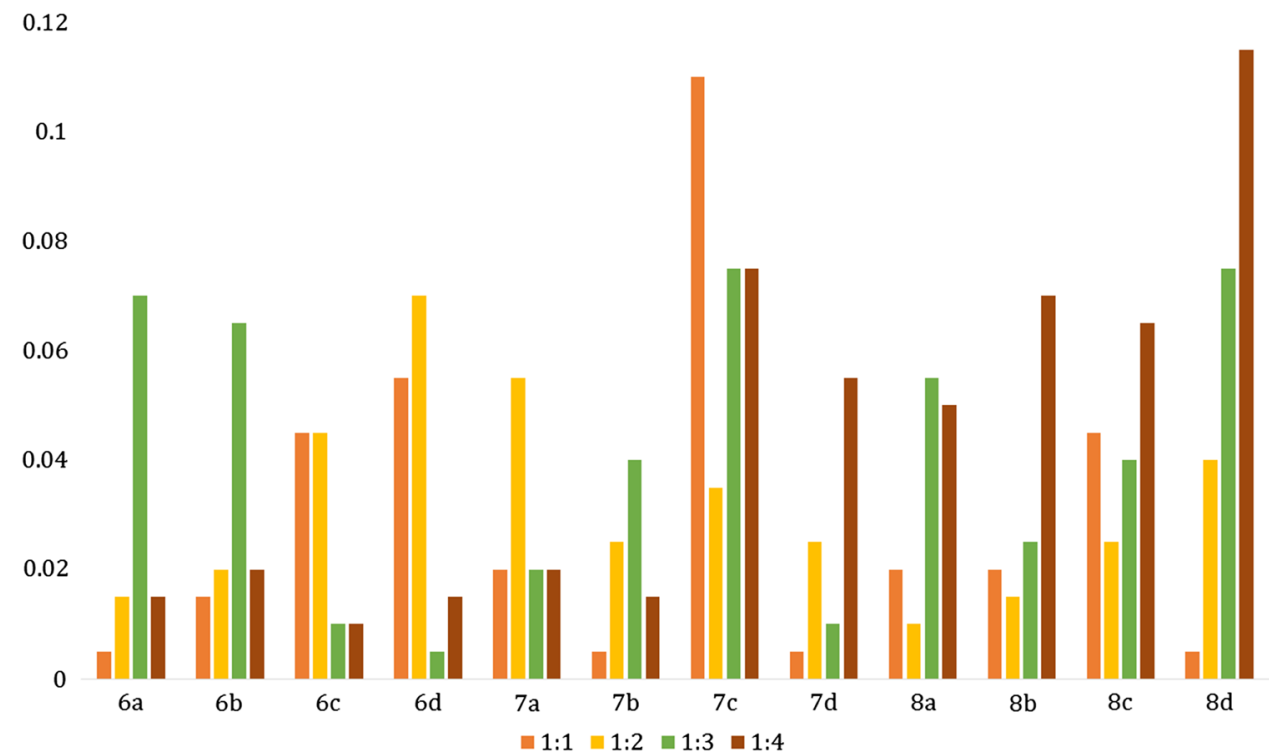

Figure 4 demonstrates the sludge obtained from the treatment, and it is observed that the sludge concentration was mostly high in 1:3 ratio.

\section{Discussion}

From the above results, it can be observed that the efficiency of blended coagulants in removal of various physicochemical parameters from the waters was better when compared to individual coagulants. Parameters like conductivity, hardness and alkalinity which are increased when treated with individual coagulants have shown removal even at less percentages when treated with blended coagulants.

Conductivity removal which was negative when treated with individual coagulants, except for chitin which has shown up to $35.71 \%$ removal, was removed successfully by blended coagulants. All the three types of blended coagulants were successful in removing electrical conductivity. Though alum and chitin combination has shown highest removal with $58.85 \%$, it was only with some precise doses of the blended coagulant, while the combination of alum, chitin and sago was most stable at all $\mathrm{pH}$ ranges and coagulant doses with $48.45 \%$ removal of electrical conductivity. 
The order of removal efficiency of electrical conductivity is alum + chitin $>$ alum + chitin + sago $>$ alum + sago .

The parameters like hardness and chlorides that have increased more than 50\% and 99\% have shown lesser increase or lower negative reduction. The order of negative removal of hardness $(-20.83 \%)$ and chlorides $(-10.53 \%)$ is as follows: alum + chitin $=$ alum + chitin + sago $=$ alum + sago and alum + chitin $>$ alum + sago $=$ alum + chitin + sago for hard ness and chlorides, respectively.

Turbidity removal was exceptionally virtuous with blended coagulants (between 86 and 99\%) when compared to individual coagulants (between 70 and $80 \%$ ). The removal of total and dissolved solids was negative with individual coagulants, whereas with blended coagulants it was observed to be between 0 and $40 \%$. Alkalinity reduction was very good with individual coagulants, whereas with blended coagulants it was recorded to be $42.86 \%$ for all the three blended coagulants.

\section{Effect of dose of coagulant}

Overdosing results in the saturation of the polymer bridge sites and causes re-stabilization of the destabilized particles and hence would also disturb particle settling (Muyibi and Evison 1995). This phenomenon happens if the mechanism of turbidity removal is through adsorption and bridging. Overdosing may also lead to charge reversal and subsequent re-stabilization of destabilized particles if the mechanism of turbidity removal is linked with adsorption and charge neutralization. This evidence is different from those reported by Katayon et al. (2006), as they documented that the optimum dosage of M. oleifera increased with increasing initial turbidity. This difference might be due to unlike experimental setups, namely, the type of water used. The present study was performed with natural surface water, while the previous one was conducted on synthetic water made up of kaolin. Surface water characteristics, type and size of particles, alkalinity and other process variables may vary from river to river, which clearly affects the performance of coagulants, unlike synthetic water samples.

Plant coagulants were even slightly more efficient than alum as reported from the first two objectives. Such result is possible and in agreement with previous work using extracts of $C$. arietinum, where natural coagulant also outperformed alum (Diaz et al. 1999; Leones and Martinez 2019).

\section{Effect of pH}

When dissolved in water, the aluminum ions are hydrolyzed and it lowers the $\mathrm{pH}$ by increasing the concentration of $\mathrm{H}^{+}$. Most likely, the naturally occurring coagulants from plant materials possess a buffering property. The study conducted by Ndabigengesere et al. (1995) and Marobhe
(2013), Muthuraman and Sasikala (2014) indicated that water treated with $M$. oleifera and $V$. unguiculata did not alter $\mathrm{pH}$ of water, whereas $\mathrm{pH}$ of a water sample augmented with increasing doses of M. oleifera and J. curcas (Marobhe 2013). Thus, using plant extracts for water treatment may have an enormous advantage by omitting the need for application of lime or bicarbonate to subsequently raise the $\mathrm{pH}$, and hence, it provides extra cost savings (Pritchard et al. 2009; Choy et al. 2014; Marobhe 2013; Šciban et al. 2009; Kaji et al. 2019). Among the tested blended coagulants, efficiency of removal of physicochemical parameters can be given as alum + chitin + sago $>$ alum + sago $>$ alum + chitin .

It was apparent that the coagulation efficiency was enhanced due to the use of combined coagulants. It should be noted that the optimum dosage of blend coagulants was found to be approximately half that of the single coagulants, which shows additional advantages for using blend coagulants. In other words, it might be possible to reduce the amount of sludge after completing coagulation and sedimentation processes by using the blend coagulants.

\section{Conclusions}

Coagulants and polymers are obtained from many natural sources, when applied as coagulants primary or auxiliary coagulation/flocculation present as viable and inexpensive alternatives for the replacement or reduction in the dosage of the coagulant metal employed in the process of treating water, and respective drawbacks are associated with these salts.

This study investigated the advantage of blended coagulants with alum and natural coagulants chitin and sago and attempted to optimize operational conditions for applying it in a coagulation process. To accomplish this goal, we evaluated the variation in physicochemical properties and turbidity to find affecting factors such as ratio of blended coagulants, coagulation $\mathrm{pH}$ and dose and compared the coagulation efficiency of single coagulants with that of the combined coagulants. The turbidity removal efficiency in such combined coagulants applied in this study was found to be $90 \%$, higher than that of single coagulants. It appeared the optimum blend ratio was $1: 1$ and 1:3. The coagulation efficiency in blended coagulants was found to be better than that of single coagulants for all $\mathrm{pH}$ conditions. The floc size in blend coagulants was larger than that of single coagulants. The data obtained in this study indicated the coagulation efficiency could be enhanced by using the blend coagulant.

In general, these products have efficiency in removal of turbidity of water, comparable or superior to that achieved by metal coagulants, spending a lower dosage. These products proved not dependent on temperature or $\mathrm{pH}$ correction and alkalinity of the water to work efficiently. In terms of 
action on the physicochemical characteristics of the clarified water, the natural polymers and coagulants show little variation in $\mathrm{pH}$, alkalinity, conductivity and concentration of cations and anions. Being from natural sources, these compounds can generate value-added products, presenting itself as a new source of income. However, despite all the associated benefits, natural coagulants and polymers should be effectively applied to the process of water clarification in scale only after undergoing tests certifying its non-toxicity, biodegradability and viability.

Open Access This article is distributed under the terms of the Creative Commons Attribution 4.0 International License (http://creativeco mmons.org/licenses/by/4.0/), which permits unrestricted use, distribution, and reproduction in any medium, provided you give appropriate credit to the original author(s) and the source, provide a link to the Creative Commons license, and indicate if changes were made.

\section{References}

Camp TR, Root DA (1940) Effects of temperature on rate of floc formation. J AWWA 32:1913

Choy SY, Prasad KMN, Wu TY, Raghunandan ME, Ramanan RN (2014) Utilization of plant-based natural coagulants as future alternatives towards sustainable water clarification. J Environ Sci 26(11):2178-2189

Dharmappa HB, Verink J, Fujiwara O, Vigneswaran S (1993) Optimal design of a flocculator. Water Res 27(3):513

Diaz A, Rincon N, Escorihuela A, Fernandez N, Chacin E, Forster CF (1999) A preliminary evaluation of turbidity removal by natural coagulants indigenous to Venezuela. Process Biochem 35:391-395

Dwarapureddi BK, Saritha V, Srinivas N, Karnena MK (2018) Trends of dissolved organic carbon in surface water treated by innate coagulants. Desalin Water Treat 136:226-236

Gidde MR, Bhalerao AR, Yawale SA (2008) Bentonite clay turbidity removal by herbal coagulant- a rural water treatment technology. In: Paper for national conference on 'Household Water Treatment Technology' at college of Sic. \&Tech. Farah, Mathura. On 24th and 25th July

Gregor JE, Nokes CJ, Fenton E (1997) Optimising natural organic matter removal from low turbidity waters by controlled $\mathrm{pH}$ adjustment of aluminium coagulation. Water Res 31:2949

Halkude SA, Pise CP (2013) Factors affecting the coagulation of turbid water with blend coagulant Moringa oleifera \& Alum. Int J Adv Res Eng Technol (IJARET) 4(4):181-190

Kaji A, Taheriyoun M, Taebi A, Nazari-Sharabian M (2019) Comparison and optimization of the performance of natural-based non-conventional coagulants in a water treatment plant. J Water Supply Res Technol Aqua. https://doi.org/10.2166/aqua.2019.075

Katayon S, Noor MMM, Asma M, Ghani LA, Thamer AM, Azni I, Ahmad J, Khor BC, Suleyman AM (2006) Effects of storage conditions of Moringa oleifera seeds on its performance in coagulation. Bioresour Technol 97:1455-1460

Kawamura S (1976) Considerations on improving flocculation. J Am Water Works Assoc 68(6):328-336

Leones MCM, Martinez IDM (2019) Clarification of the water of wetlands using a mixture of natural coagulants. DYNA 86(209):80-85

Marobhe NJ (2013) Effectiveness of crude extract and purified protein from Vigna unguiculata seed in purification of charco dam water for drinking in Tanzania. Int J Environ Sci 4:3

Mhaisalkar VA, Paramasivam R, Bhole AG (1991) Optimizing physical parameters of rapid mix design for coagulation-flocculation of turbid waters. Water Res 25:43

Morris JK, Knocke WR (1984) Temperature effects on the use of metal-ion coagulants for water treatment. J AWWA 76:74

Muthuraman G, Sasikala S (2014) Removal of turbidity from drinking water using natural coagulants. J Ind Eng Chem 20(4):1727-1731

Muyibi SA, Evison LM (1995) Moringa oleifera seeds for softening hard water. Water Res 29(4):1099-1105

Myung BT, Woo DS, Choi JH, Lee YJ, Nam SH (2001) Kor J Environ Health Soc 27:60

Ndabigengesere A, Narasiah KS, Talbot BG (1995) Active agents and mechanism of coagulation of turbid waters using Moringa oleifera. Water Res 29:703-710

Pritchard M, Mkandawire T, Edmondson A, O’Neill JG, Kululanga G (2009) Potential of using plant extracts for purification of shallow well water in Malawi. Phys Chem Earth 34:799-805

Rossini M, Garrido JG, Galluzzo M (1999) Optimization of the coagulation-flocculation treatment: influence of rapid mix parameters. Water Res 33:1817

Saritha V, Karnena MK, Dwarapureddi BK (2019) "Exploring natural coagulants as impending alternatives towards sustainable water clarification"-a comparative studies of natural coagulants with alum. J Water Process Eng 32:100982

Šćiban M, Klašnja M, Antov M, Škrbić B (2009) Removal of water turbidity by natural coagulants obtained from chestnut and acorn. Biores Technol 100(24):6639-6643

Semmens MJ, Field TK (1980) Coagulation: experiences in organics removal. J Am Water Works Assoc 72(8):476-483

Vara S (2012) Screening and evaluation of innate coagulants for water treatment: a sustainable approach. Int J Energy Environ Eng 3(1):29

Publisher's Note Springer Nature remains neutral with regard to jurisdictional claims in published maps and institutional affiliations. 